\title{
The Goudge Inquiry and the role of medical expert witnesses
}

\author{
Hon. Frank lacobucci BCom LLD, Graeme Hamilton MA JD
}

Previously published at www.cmaj.ca

$\mathrm{T}$ he expansion of human knowledge requires that courts of law increasingly rely on expert witnesses, including medical expert witnesses, in their search for the truth. But as several recent cases have illustrated, the unfettered use of experts in judicial proceedings can have tragic consequences. In Ontario, the expert testimony of Dr. Charles Smith, a pediatric forensic pathologist, has been linked to several miscarriages of justice and resulted in an official inquiry conducted by Justice Stephen Goudge. In his report, Goudge identified several concerns regarding the interaction between medical expert witnesses and the justice system. ${ }^{1}$ The medical community should be informed of these concerns, so that any physicians testifying as expert witnesses are aware of their proper role and can thus help to safeguard the integrity of the justice system.

\section{Goals of the adversarial system}

Achieving justice in a legal proceeding is generally based on revealing the truth. Common law jurisdictions, including Australia, Canada, England and Wales, and the United States, use an adversarial style of proceeding, on the premise that an oppositional presentation of the relevant evidence before an impartial decision-maker is the best means of seeking the truth while ensuring that the other goals of the justice system, including treating the parties fairly and serving as a check on government tyranny, are met. ${ }^{2}$ This adversarial process is markedly different from the inquisitorial process used in continental Europe and elsewhere, where control of the fact-gathering process is ceded to a judge, who has broad discretion to conduct the inquiry as he or she sees fit. ${ }^{2}$

Expert witnesses have served the truth-seeking function of adversarial proceedings since the Middle Ages. In 1345, a court summoned surgeons to examine a wound in deciding whether a case should proceed to trial. A man had been charged with mayhem, an offence that involved maiming another man so as to impair his ability in combat. The court sought the surgeons' assistance to determine whether the wound was fresh. ${ }^{3}$

Today, the gap between a layperson's knowledge and that of an expert is vast and growing in virtually all domains. It is vital to the pursuit of justice that the judge or jury have access to the specialized knowledge of experts when it is likely that such knowledge will be required to arrive at the truth.

\section{Key points}

- The Inquiry into Pediatric Forensic Pathology in Ontario (the Goudge Inquiry) concluded that interactions between medical expert witnesses and the justice system can be problematic.

- To prevent miscarriages of justice, the medical community needs to be aware of the expert witness's role in the justice system and the challenges that expert testimony poses to the system.

- The expert's role is to help the judge or jury reach the correct fact-based inference in cases where someone with only a layperson's knowledge or experience is unlikely to make that inference.

- The overriding duty of any expert witness is to assist the court by providing impartial testimony, regardless of who retained the witness.

\section{Role of the expert in the adversarial system}

Expert witnesses undoubtedly play a vital role in the justice system, but that role must be strictly defined. In general, a strict dichotomy is observed between the role of witnesses and the role of the trier of fact. Witnesses testify to the bare facts (what they saw, heard, said, etc.), whereas the trier of fact forms opinions and draws conclusions based on the witnesses' testimony.

As an exception to this general rule, expert witnesses are permitted to offer opinions because the law recognizes that judges and juries are not readily able to form opinions on some matters. Expert opinions are permitted in situations where someone with a layperson's knowledge or experience is unlikely to reach the correct inference from the facts alone. ${ }^{4,5}$ For instance, a toxicologist would be permitted to testify that symptoms observed in a patient seen in the emergency department were, in his opinion, consistent with poisoning.

There are four primary reasons to scrupulously control the use of expert witnesses in legal proceedings. First, the unfettered use of experts tends to undermine the rationality of the legal process, ${ }^{6}$ which requires that all relevant facts be put before the court and that a decision or verdict be reached through an impartial and

The Honourable Frank lacobucci is Counsel at Torys LLP, Toronto, Ont., having retired as a Justice of the Supreme Court of Canada in 2004. Graeme Hamilton is a lawyer with Patrick Schindler, Barristers in Toronto and is currently pursuing graduate studies at Harvard Law School, Cambridge, USA.

CMAJ 2009. DOI:10.1503/cmaj.090833 
reasoned application of the law to the facts. Impressive credentials can sway juries, judges and even lawyers for opposing parties. ${ }^{1,7}$ So-called hired guns sometimes skew their testimony toward the side that hired them, rather than providing a balanced view of the merits of competing theories. ${ }^{1,8}$ In addition, the use of experts tends to increase the complexity of trials, since often the only means of rebutting an opposing party's expert opinion is through the conflicting opinion of another expert. ${ }^{8}$

Second, the justice system's pursuit of the truth is not absolute; it is attenuated where necessary to ensure fairness or to preserve the integrity of the administration of justice. In this regard, expert testimony brings to the fore two important issues. Notably, the high cost of retaining experts impedes equal access to justice and raises concerns about the fairness of the judicial system. ${ }^{7,8}$ In addition, when litigants are able to parade experts advancing dubious pseudoscientific theories in front of the judge or jury, the administration of justice is brought into disrepute. This is also the case when a trial is allowed to devolve into a "battle of the experts," with both sides presenting supposedly objective and irrefutable — but nevertheless conflicting - evidence.

The third reason to control the use of experts is that courts are not particularly qualified to assess the reliability of an expert's testimony. Lawyers and judges often lack even basic scientific literacy. ${ }^{1,4}$ Furthermore, often a complex substratum of fact and theory underlies the expert's opinion, and it can be difficult both for a lawyer to navigate through this information when challenging the witness during cross-examination and for the judge or jury to follow.

Fourth, our justice system requires that the judge or jury resolve questions of fact, and there is often a fine line between aiding the fact-finder and usurping him or her. For example, a physician may testify to the applicable standard of care in a medical malpractice suit, but it would be impermissible for the physician to state a belief that the defendant was negligent, because this is a legal determination to be made by the judge or jury.

\section{Jurisprudence on the role of the expert}

With all the foregoing in mind, legal rules have evolved to provide guidelines limiting the use of experts in legal proceedings. In $R$. v. Mohan, the Supreme Court of Canada laid down a 4-part test for determining the admissibility of expert evidence: ${ }^{9}$

1. The evidence must be relevant: it must tend to establish a fact in issue, and the value of the evidence must outweigh the costs of introducing it into the trial process.

2. The evidence must be necessary to assist the judge or jury. Expert evidence is not permitted on matters about which laypersons are expected to be knowledgeable.

3. The expert evidence must not be inadmissible on any other basis. Apart from the rule excluding opinion evidence, there are many other statutory and common law rules governing the admissibility of evidence. This third part of the test is simply to ensure that parties do not use expert witnesses to introduce, through the "back door," evidence that would otherwise be inadmissible.

4. The expert must have specialized knowledge of the subject about which he or she is testifying, and testimony that is beyond the expert's area of expertise is inadmissible. For example, a plastic surgeon who specializes in treating childhood burn injuries would not be permitted to testify that a child's passivity during a physical examination is suggestive of abuse. ${ }^{10}$

Although reliability is not among the four criteria identified in $R$. v. Mohan, the reliability of an expert's opinion will affect its relevance. An unreliable opinion is considered unduly prejudicial to the fact-finding process and should be excluded. It follows that judges are required to assess the reliability of an opinion. This can be challenging if the opinion is based on a novel or controversial theory, such as the theory that trauma precipitates the onset of multiple sclerosis or the exacerbation of symptoms of multiple sclerosis. ${ }^{11}$ It can similarly be challenging if the opinion is based on a novel or controversial analytical technique, such as the use of positron emission tomography to diagnose mild traumatic brain injury ${ }^{12}$ or the use of mitochondrial DNA typing for forensic identification. ${ }^{13}$

The US and Canadian Supreme Courts have indicated that in these circumstances, judges must conduct an independent inquiry into the reliability of the theory. ${ }^{14,15}$ They cannot simply defer to the scientific community to determine whether a theory has been generally accepted. Although the scientific community's view of the theory is relevant, judges must independently consider such matters as whether a technique or theory can be and has been tested, whether it is explained or cited in peer-reviewed literature, and the known or potential error rate associated with it. ${ }^{14}$

\section{Issues regarding the role of medical experts}

Unfortunately, the legal rules described above have proven insufficient to safeguard the integrity of the justice system as it attempts to grapple with the proliferation of medical expert testimony. There have been several highly publicized incidents in Australia, Canada, England and Wales, and the United States where the testimony of discredited medical experts has been implicated in known and potential miscarriages of justice. ${ }^{1,16-18}$ As the latest word on the role of experts, Goudge's recent report into pediatric forensic pathology in Ontario highlighted several additional issues that came to the fore through an examination of Dr. Charles Smith's work. ${ }^{1}$

Smith was a Toronto-based pediatric pathologist who was widely recognized in Canada as an expert in pediatric forensic pathology during the 1990s. However, concerns began to surface about his methods and conclusions, which ultimately led to a 2005 coroner's review of all criminally suspicious cases, from 1991 forward, in which Smith had conducted the autopsy or been consulted. The five eminent forensic pathologists who undertook the review questioned Smith's opinions in 20 of the 45 cases they examined, 12 of which had resulted in findings of guilt. As a consequence of this problematic finding, the Ontario government established a Commission of Inquiry to probe the systemic failings that allowed Smith to continue unchecked for so long. ${ }^{1}$

In his report, Goudge expressed several concerns regarding the manner in which forensic pathologists interact with the justice system. Among his concerns were the following: the nature of the opinions given by forensic pathologists, the means by 
which pathologists substantiate their conclusions, the ways in which pathologists deliver their opinions and the expert witness's general awareness of his or her role in the justice system. In some of the cases examined by the Inquiry, Smith's testimony was challenged by experts retained by the defence. In others, it was not. In any event, Goudge's concerns - which revolve around the intelligibility of an expert's testimony to the parties, their lawyers, the judge and the jury — are operative in both situations (i.e., where testimony is rebutted by another expert and where it is not) and in civil proceedings as well.

\section{Nature of the expert witness's opinions}

With respect to Goudge's first concern, he found that Smith had been allowed to offer opinions that he was not qualified to give. On two occasions, Smith had gone so far as to provide profiles of the perpetrators of shaking and blunt head injuries, despite the fact that his training was in pathology, not psychology. ${ }^{1}$

Lacking broad knowledge of an expert's discipline, the court is ill-equipped to ensure that an expert stays within his or her area of expertise. For example, when Smith claimed that as a pediatric pathologist he was better situated than a certified forensic pathologist to diagnose stab wounds in children, the court accepted his claim, ${ }^{1}$ because it seemed quite reasonable to someone outside the medical community.

It is likewise difficult for the court to determine whether a scientific expert's opinion is properly grounded in science. Scientific reports use technical terms that do not translate easily into everyday English. Lawyers and judges must grapple with this unfamiliar language, which can make the process of following the scientist's logic very difficult. Furthermore, lawyers, judges and juries often lack the intuition for the scientific method that scientists develop through years of education and experience and are therefore less likely to identify weaknesses in an expert's opinion.

\section{Means of substantiating conclusions}

With respect to Goudge's second concern — the means by which pathologists substantiate their conclusions - he found that Smith routinely offered opinions without stating the underlying empirical evidence and reasoning. ${ }^{1}$ Indeed the Inquiry found that, until recently, it was not common practice for pathologists to explain in their postmortem reports how they arrived at their opinions on cause of death. ${ }^{1}$

In addition, it is unclear what sort of reasoning is permissible. For instance, there is debate regarding the extent to which a pathologist may rely on circumstantial evidence ${ }^{1}$ or his own experience in other cases ${ }^{19}$ when forming conclusions about a person's cause of death. Pathologists who testified before the Goudge Inquiry had differing opinions regarding how much reliance could be placed on circumstantial evidence. ${ }^{1}$ While the Ontario Court of Appeal recently rejected a pathologist's opinion that was based solely on his own experience and was not supported by peer-reviewed studies, ${ }^{19}$ it is not clear that medical experts' opinions must (or should) always be supported by a relevant body of scientific literature. Some might argue that the justice system should have the benefit of cutting-edge scientific knowledge as it develops, rather than waiting until it appears in scientific journals.

\section{Delivery of the expert witness's opinions}

With respect to Goudge's third concern - the ways in which pathologists deliver their opinions - he found that Smith's opinions were sometimes vulnerable to misinterpretation. For example, Smith used the term "asphyxia" without clarifying that he intended the benign scientific meaning, not the inculpatory meaning. ${ }^{1}$ He was also sometimes unclear about his level of confidence in his opinion about the deceased's cause of death. ${ }^{1}$ Such testimony is problematic, according to Goudge, because participants in the justice system are continually distilling complex and nuanced opinions to make them intelligible for purposes of deliberation, ${ }^{1}$ and ambiguous testimony makes this task much more difficult. Although it is vital that experts use straightforward language in their reports and testimony, ${ }^{1}$ it is unclear how the law should ensure that they do so.

\section{Awareness of the role of the expert witness}

With respect to Goudge's fourth concern - the expert witness's awareness of his or her role — he found that Smith was unaware that experts are expected to provide impartial testimony and that their overriding duty is to assist the court. Instead, Smith sometimes acted like a partisan advocate for the prosecution, ${ }^{1}$ overstating his level of confidence in his opinions and failing to identify plausible alternative theories where they existed.

Ideally, when an expert is not being objective, the process of cross-examination should ferret out gaps in the expert's testimony and should result in alternative hypotheses being put before the court. ${ }^{4,7}$ However, to highlight any methodologic or logical shortcomings associated with the evidence, effective cross-examination requires knowledge of both the expert's subject matter and the basic principles of the scientific method. ${ }^{1,20}$ In many cases, it will also be necessary for the opposing side to retain its own experts to review the opinion in front of the court. ${ }^{8}$ Unfortunately, not all lawyers are up to the task of crossexamining experts - as Goudge highlighted in his report ${ }^{1}$ and the cost of retaining one's own expert can be prohibitive. , $^{821}$

Although the Inquiry canvassed arguments regarding the use of court-appointed or jointly appointed experts as a means of obtaining reliable and objective testimony ${ }^{1,22}$ and although judges in common law jurisdictions are typically able to appoint experts, mandating the use of joint or court-appointed experts would, in the words of one commentator, "constitute a more conspicuous departure from conventional adversarial processes." 23 The presentation of conflicting experts' opinions on scientific topics in open court is the natural extension of the fact-finding method that the adversarial system generally employs. Were courts to appoint experts or force the parties to compromise on a joint expert, the ability of both sides to make the most favourable presentation of all the relevant evidence would be impeded and the judicial process could be perceived as unfair. ${ }^{23}$ Furthermore, it is unclear how controversies in the relevant science would be revealed and resolved before the court. The judge's or the jury's task would undoubtedly be easier without contradictory expert testimony, but this does not necessarily justify glossing over matters of scientific controversy. ${ }^{23}$ Finally, as Goudge pointed out, Smith is the very sort of "well-known expert" likely to be appointed by the court." 


\section{Box 1: What is an expert witness to do?*}

It may be helpful to the judicial process if:

- Expert witnesses expressed opinions only on matters within their area of expertise, gained either through specialized training or through experience.

- Expert witnesses were explicit about the facts and reasoning underlying their conclusions and related them back to the relevant literature where possible.

- Expert witnesses avoided using scientific jargon when they testify and clarified their usage of any word or term not being used in its ordinary sense.

- Expert witnesses identified any opinion that is qualified and acknowledged any controversies in the underlying science.

- Expert witnesses were apprised of their role before being retained in a legal proceeding, being informed specifically that their primary obligation is to assist the court by providing impartial testimony.

*Based on recommendations made in the Inquiry into Pediatric Forensic Pathology in Ontario (the Goudge Inquiry).

In Australia and in England and Wales, judges and legislators have implemented various measures to ensure that experts are aware that their overriding duty is to the court. ${ }^{24-26}$ Similar efforts are now under way in some Canadian jurisdictions. ${ }^{27,28}$ For instance, amendments to Ontario's Rules of Civil Procedure, which come into effect on Jan. 1, 2010, require experts to sign an acknowledgement that they are aware that their duty is to provide opinion evidence that is "fair, objective and nonpartisan" and that this duty prevails over any obligation owed to the party retaining the expert. ${ }^{27}$ However, contributors to the Goudge Inquiry made the valid point that such measures do not guarantee that expert witnesses will act in accordance with their duty. ${ }^{1}$

\section{Conclusion}

Several commentators have suggested that, when the adversarial system is working as it should, our courts are a robust forum for highlighting matters of scientific controversy. ${ }^{1,23,29}$ Goudge's report is a tragic narrative of the mischief that results when the system is not functioning effectively.

There is no one particular cure that will guarantee the integrity of the system. Relying on legal rules alone has proven ineffective. To function well, the system requires that judges, lawyers and expert witnesses all do their part. Lawyers should not take on cases that involve complex medical evidence unless they are scientifically literate. ${ }^{1}$ Each time a party calls an expert witness to testify, the judge must carefully consider whether to "qualify" the expert on the basis of his or her expertise and the testimony he or she intends to give. ${ }^{1,6}$ Judges must also remain vigilant once an expert takes the stand and must ensure that the expert does not stray from his or her area of expertise. ${ }^{1}$ Finally, expert witnesses must give fair, objective and impartial testimony, irrespective of whether they have been retained by a party or appointed by the court. ${ }^{1}$ They must also be sensitive to the vulnerabilities of the system and do their utmost to present evidence in a manner that ensures its intelligibility (Box 1).

This article has been peer reviewed.

Competing interests: None declared.

Contributors: Both authors were responsible for the conception and design of the article and the analysis presented therein. Both authors were involved in drafting and revising the article for important intellectual content, and both read the final version to be published and approved its contents.

\section{REFERENCES}

1. Goudge ST. Inquiry into pediatric forensic pathology in Ontario. Toronto (ON): Ontario Ministry of the Attorney General; 2008.

2. Landsmann S. The adversary system: a description and defense. Washington (DC): The American Enterprise Institute; 1984.

3. Hand BL. Historical and practical considerations regarding expert testimony. Harv Law Rev 1901;15:40-58.

4. Anderson GR. Expert evidence. Markham (ON): LexisNexis; 2005

5. R. v. Abbey, [1982] 2 SCR 24.

6. Beecher-Monas E. Evaluating scientific evidence: an interdisciplinary framework for intellectual due process. New York (NY): Cambridge University Press; 2007.

7. R. v. D.D., [2000] 2 SCR 275

8. Osborne CA. Civil justice reform project: summary of findings and recommendations. Toronto (ON): Ontario Ministry of the Attorney General; 2007. Available: www.attorneygeneral.jus.gov.on.ca/english/about/pubs/cjrp (accessed 2009 Apr. 22).

9. R. v. Mohan, [1994] 2 SCR 9.

10. R. v. Marquard, [1993] 4 SCR 223

11. Taylor v. Liong, [2007] BCJ No. 330.

12. Wolfin v. Shaw (1998), 43 BCLR (3d) 190.

13. $R$. v. Murrin (1999), 181 DLR (4th) 320.

14. Daubert v. Merrell Dow Pharmaceuticals Inc., 509 US 579 (1993).

15. R. v. J.-L.J., [2000] 2 SCR 600.

16. Driscoll M. His legacy of shattered lives. Sunday Times [London (UK)] 2004 Jan. 25. Available: www.timesonline.co.uk/tol/news/article1061437.ece (accessed 2009 Apr. 29).

17. Archer G. The plot thickens in Keogh murder case. Independent Weekly [Adelaide (South Australia)] 2008 Nov. 4. Available: www.independentweekly.com.au/news /local/news/general/the-plot-thickens-in-keogh-murder-case/421286.aspx (accessed 2009 Apr. 29).

18. Levs ML. Bite-mark evidence loses teeth. Am Bar Assoc J 2008;94:16. Available: www.abajournal.com/magazine/article/bite mark_evidence loses teeth/ (accessed 2009 Nov. 23)

19. Truscott (Re) (2007), 225 CCC (3d) 321 (Ont. CA)

20. Gold AD. Expert evidence in criminal law: the scientific approach. Toronto (ON): Irwin; 2003.

21. Consultation Memorandum 12.3: Expert evidence and independent medical examinations. In: Alberta Rules of Court Project. Edmonton (AB): Alberta Law Reform Institute; 2003. Available: www.law.ualberta.ca/alri/Publications/ConsultationMemoranda.php (accessed 2009 Apr. 24).

22. Rt. Hon. Lord Woolf. Chapter 13: Expert evidence. In: Access to justice: final report to the Lord Chancellor on the civil justice system in England and Wales. London (UK): Department of Constitutional Affairs; 1996. Available: www.dca.gov.uk/civil/final/sec3c.htm\#c13 (accessed 2009 Apr. 29).

23. Edmond G. Secrets of the "Hot Tub": expert witnesses, concurrent evidence and judge-led law reform in Australia. Civ Justice Q 2008;27:51-82.

24. R. v. Harris and others, [2005] EWCA Crim 1980.

25. Criminal Procedure (Amendment No. 2) Rules 2006, S.I. 2006/2636, r. 19

26. Edmond G. After objectivity: expert evidence and procedural reform. Syd Law Rev 2003;25:131-63.

27. Rules of Civil Procedure, amending Reg. 194 of R.R.O. 1990, O. Reg. 438/08, s. 48.

28. Concept draft: proposed new rules of civil procedure of the British Columbia Supreme Court. Vancouver (BC): BC Justice Review Task Force; 2008. Available: www.bcjusticereviewforum.ca/civilrules/downloads/civilrules_conceptdraft_may2008 .pdf (accessed 2009 Apr. 24).

29. Jasanoff S. Science at the bar: law, science and technology in America. Cambridge (MA): Harvard University Press; 1995

Correspondence to: $\mathrm{Mr}$. Graeme Hamilton, Associate, Patrick Schindler, Barristers, 401 Bay Street, Ste. 2112, Toronto ON

M5H 2Y4; graeme@ patrickschindler.com 